\title{
Front Matter: Volume 9573
}

, "Front Matter: Volume 9573," Proc. SPIE 9573, Optomechanical Engineering 2015, 957301 (8 September 2015); doi: 10.1117/12.2208518

SPIE Event: SPIE Optical Engineering + Applications, 2015, San Diego, California, SPIE. United States 


\title{
PROCEEDINGS OF SPIE
}

\section{Optomechanical Engineering 2015}

\author{
Alson E. Hatheway
}

Editor

10-12 August 2015

San Diego, California, United States

Sponsored and Published by

SPIE 
The papers included in this volume were part of the technical conference cited on the cover and title page. Papers were selected and subject to review by the editors and conference program committee. Some conference presentations may not be available for publication. The papers published in these proceedings reflect the work and thoughts of the authors and are published herein as submitted. The publisher is not responsible for the validity of the information or for any outcomes resulting from reliance thereon.

Please use the following format to cite material from this book:

Author(s), "Title of Paper," in Optomechanical Engineering 2015, edited by Alson E. Hatheway, Proceedings of SPIE Vol. 9573 (SPIE, Bellingham, WA, 2015) Article CID Number.

ISSN: 0277-786X

ISBN: 9781628417395

Published by

SPIE

P.O. Box 10, Bellingham, Washington 98227-0010 USA

Telephone +1 3606763290 (Pacific Time) · Fax +1 3606471445

SPIE.org

Copyright $@ 2015$, Society of Photo-Optical Instrumentation Engineers.

Copying of material in this book for internal or personal use, or for the internal or personal use of specific clients, beyond the fair use provisions granted by the U.S. Copyright Law is authorized by SPIE subject to payment of copying fees. The Transactional Reporting Service base fee for this volume is $\$ 18.00$ per article (or portion thereof), which should be paid directly to the Copyright Clearance Center (CCC), 222 Rosewood Drive, Danvers, MA 01923. Payment may also be made electronically through $\mathrm{CCC}$ Online at copyright.com. Other copying for republication, resale, advertising or promotion, or any form of systematic or multiple reproduction of any material in this book is prohibited except with permission in writing from the publisher. The CCC fee code is $0277-786 \mathrm{X} / 15 / \$ 18.00$.

Printed in the United States of America.

Publication of record for individual papers is online in the SPIE Digital Library.

\section{SPIE. DIGITAL \\ SPIEDigitalLibrary.org}

Paper Numbering: Proceedings of SPIE follow an e-First publication model, with papers published first online and then in print. Papers are published as they are submitted and meet publication criteria. A unique citation identifier (CID) number is assigned to each article at the time of the first publication. Utilization of CIDs allows articles to be fully citable as soon as they are published online, and connects the same identifier to all online, print, and electronic versions of the publication. SPIE uses a six-digit CID article numbering system in which:

- The first four digits correspond to the SPIE volume number.

- The last two digits indicate publication order within the volume using a Base 36 numbering system employing both numerals and letters. These two-number sets start with 00, 01, 02, 03, 04, $05,06,07,08,09,0 A, 0 B \ldots$. OZ, followed by 10-1Z, 20-2Z, etc.

The CID Number appears on each page of the manuscript. The complete citation is used on the first page, and an abbreviated version on subsequent pages. 


\title{
Contents
}

\author{
$\checkmark$ Authors \\ vii Conference Committee
}

\section{SYSTEM TESTING AND MATERIALS}

957303 In-situ mitigation of radiation-induced attenuation in optical fiber used for sensing at nuclear facilities [9573-2]

$957304 \quad$ ZERODUR ${ }^{\circledR}:$ new stress corrosion data improve strength fatigue prediction [9573-3]

957305 Effect of major factors on damage threshold of optical rectification crystals [9573-5]

\section{APPLICATIONS OF 3D PRINTING}

957306 Optomechanical performance of 3D-printed mirrors with embedded cooling channels and substructures [9573-6]

957307 Extended volume and surface scatterometer for optical characterization of 3D-printed elements [9573-7]

957308 Optical fabrication of lightweighted 3D printed mirrors [9573-8]

957309 3D-additive manufactured optical mount [9573-9]

\section{SYSTEM DESIGN}

9573 OB Elliptically framed tip-tilt mirror optimized for stellar tracking [9573-11]

9573 OC Contamination and UV lasers: lessons learned [9573-12]

\section{LOW COST SPACE OPTICS}

9573 OE Cost-optimized methods extending the solution space of lightweight monolithic ZERODUR ${ }^{\circledR}$ mirrors to larger sizes [9573-14]

9573 OF Selection considerations between ZERODUR® and silicon carbide for dimensionally-stable spaceborne optical telescopes in two-earth-orbits [9573-15]

9573 OG Evolving design criteria for very large aperture space-based telescopes and their influence on the need for intergrated tools in the optimization process [9573-16] 
$9573 \mathrm{OH} \quad$ Recent updates to the Arnold Mirror Modeler and integration into the evolving NASA overall design system for large space-based optical systems [9573-17]

\section{OPTOMECHANICAL ANALYSIS}

9573 Ol Novel applications of active mirror analysis [9573-18]

9573 OJ Shear stresses in cemented and bonded optics due to temperature changes [9573-19]

9573 OK Unified optomechanical modeling: thermo-elastic stability of a fiber optic diffractive encoding system [9573-20]

9573 OL Light source heat absorption analysis of a Dyson-type lithography lens [9573-21]

\section{OPTICAL ELEMENT FABRICATION}

$95730 \mathrm{M}$ Techniques for analyzing lens manufacturing data with optical design applications (Invited Paper) [9573-22]

9573 ON Dependency between removal characteristics and defined measurement categories of pellets [9573-23]

957300 Q-switched 1064nm laser source for photomechanical ablation in obsidianus lapis [9573-24]

9573 OP Residue stress analysis of molding aspherical plastic lens [9573-25]

$95730 Q \quad$ A high contrast 400-2500 nm hyperspectral checkerboard consisting of Acktar material cut with a femto second laser [9573-26]

\section{COMPONENT MOUNTING}

9573 OR Unit moment analysis as a guide to mirror mount design [9573-27]

9573 OS Mechanical design of a precision linear flexural stage for 3D x-ray diffraction microscope at the Advanced Photon Source [9573-28]

9573 OT Pre-construction of giant steerable science mirror for TMT [9573-29]

\section{POSTER SESSION}

$9573 \mathrm{OU} \quad$ Aligning and measuring the curvature and thickness of high-precision lens [9573-4]

$95730 \mathrm{~V}$ Analysis investigation of supporting and restraint conditions on the surface deformation of a collimator primary mirror [9573-30]

9573 OW Development of 1-m primary mirror for a spaceborne camera [9573-31] 


\section{Authors}

Numbers in the index correspond to the last two digits of the six-digit citation identifier (CID) article numbering system used in Proceedings of SPIE. The first four digits reflect the volume number. Base 36 numbering is employed for the last two digits and indicates the order of articles within the volume. Numbers start with 00, 01, 02, 03, 04, 05, 06, 07, 08, 09, 0A, 0B...0Z, followed by 10-1Z, 20-2Z, etc.

Aguilar-Morales, A. I., 00

Álvarez-Chávez, J. A., 00

An, Qichang, OT

Anton, J., OS

Arnold, William R., Sr., OG, $\mathrm{OH}$

Bates, Richard, 08

Brisson, Erik, 06

Calis, Jacob, 08

Chan, Chia-Yen, OV

Chang, Shenq-Tsong, OL, OP, OU

Chen, Yi-Cheng, OV

Cheng, Yuan-Chieh, OP

Ciscel, David, 09

Clark, James H., III, OB

Coronato, Patrick, OR

Daly, John G., OC

Dannenberg, Florian, 07

De La Torre, Alyssa, 08

Frayer, Daniel K., OM

Genberg, Victor, OI

Goodarzi, Mohammad, $\mathrm{OQ}$

Gregory, Michael K., OM

Guo, Peng, OT

Hahlweg, Cornelius, 07

Hartmann, Peter, 04

Hatheway, Alson E., OK

Henrottin, Anne, $0 Q$

Herzog, Harrison, 08

Ho, Cheng-Fang, OL

Holbert, Keith E., 03

Hsu, Ming-Ying, OL, OP, OU

Hsu, Wei-Yao, OU

Huang, Bo-Kai, OV

Huang, Ting-Ming, OL, OP, OU, OV

Hull, Tony, OE, OF

Jiang, Haibo, OT

Kaufman, Morris I., OM

Kearney, S., OS

Keresztes, Janos C., OQ

Kihm, Hagyong, OW

Kim, Dae Wook, 08

Kleer, Günter, 04

Lee, Yun-Woo, OW

Leys, Antoine, OE

Light, Brandon B., OM

Liu, W., OS

Malone, Robert M., OM

Mammini, Paul V., 09

Meng, Qinglong, 05
Michels, Gregory, 01

Mici, Joni, 06, 08

Mireles, Jorge, 08

Morales-Ramírez, A. J., 00

Ortega-Delgado, M. A., 00

Panzner, Michael, 00

Penado, F. Ernesto, OB

Pescoller, Lukas, 07

Petak, Jeremy, OB

Povilaitis, Reinhold Z., 03

Rascher, R., ON

Rhee, Hyug-Gyo, OW

Rist, Tobias, 04

Rohrbacher, M., ON

Rothenberg, Bradley, 06

Saeys, Wouter, $0 Q$

Segal, Jacob, 08

Shu, D., OS

Sinzinger, S., ON

Smith, Jeremy, 08

Stubbs, David M., 06, 08

Su, Zhuolin, 05

Tischler, J. Z., OS

Tseng, Shih-Feng, OU

Uebeler, Denise, 07

van Roy, Jeroen, $0 Q$

Vogt, C., ON

Vukobratovich, Daniel, OJ, OR

Weidmann, Gunter, OF

Weiß, Jürgen, 07

Westerhoff, Thomas, OE, OF

Weyer, Cornelia, 07

Wicker, Ryan, 08

Wicks, Sunny, 06

Wooten, John, 09

Wouters, Niels, $0 Q$

Wu, Kun-Huan, OU

Yang, Fei, OT

Yang, Ho-Soon, OW

Yoder, P. R., Jr., OJ

You, Zhen-Ting, OV

Yu, Junli, 05

Zhang, Bin, 05

Zhao, Hongchao, ОT 
Proc. of SPIE Vol. $9573957301-6$

Downloaded From: https://www.spiedigitallibrary.org/conference-proceedings-of-spie on 26 Apr 2023 Terms of Use: https://www.spiedigitallibrary.org/terms-of-use 


\section{Conference Committee}

Program Track Chair

H. Philip Stahl, NASA Marshall Space Flight Center (United States)

Conference Chair

Alson E. Hatheway, Alson E. Hatheway Inc. (United States)

Conference Program Committee

Anees Ahmad, Raytheon Missile Systems (United States)

Patrick A. Bournes, MicroMeasure, Inc. (United States)

James H. Burge, College of Optical Sciences, The University of Arizona (United States)

John M. Casstevens, Dallas Optical Systems, Inc. (United States)

Robert Gifford Chave, RCAP Inc. (United States)

Patrick A. Coronato, Raytheon Missile Systems (United States)

John G. Daly, Vector Engineering (United States)

Keith B. Doyle, MIT Lincoln Laboratory (United States)

Robert C. Guyer, BAE Systems (United States)

Mark J. Hegge, Ball Aerospace \& Technologies Corporation (United States)

Tony Hull, University of New Mexico at Albuquerque (United States)

Frank W. Kan, Simpson Gumpertz \& Heger Inc. (United States)

William Jeffrey Lees, Johns Hopkins University Applied Physics Laboratory (United States)

John J. Polizotti, BAE Systems (United States)

Santiago Royo Royo, Universidad Politècnica de Catalunya (Spain)

Ann F. Shipley, University of Colorado at Boulder (United States)

Deming Shu, Argonne National Laboratory (United States)

David M. Stubbs, Lockheed Martin Space Systems Company

(United States)

Linda C. Usher, Executive Search Group (United States)

Daniel Vukobratovich, Raytheon Missile Systems (United States)

Paul R. Yoder Jr., Consultant (United States)

Carl H. Zweben, Consultant (United States)

Session Chairs

1 System Testing and Materials

Alson E. Hatheway, Alson E. Hatheway Inc. (United States) 
2 Applications of 3D Printing

David M. Stubbs, Lockheed Martin Space Systems Company (United States)

3 System Design

Alson E. Hatheway, Alson E. Hatheway Inc. (United States)

4 Optical Product Readiness

Alson E. Hatheway, Alson E. Hatheway Inc. (United States)

5 Low Cost Space Optics

Alson E. Hatheway, Alson E. Hatheway Inc. (United States)

6 Optomechanical Analysis

Anees Ahmad, Raytheon Missile Systems (United States)

7 Optical Element Fabrication

Mark J. Hegge, Ball Aerospace \& Technologies Corporation (United States)

8 Component Mounting

Alson E. Hatheway, Alson E. Hatheway Inc. (United States) 